\title{
What Determines the Use of Capital Budgeting Methods? Evidence from Swedish Listed Companies
}

\author{
Sven-Olov Daunfeldt ${ }^{1, *}$, Fredrik Hartwig ${ }^{2}$ \\ ${ }^{1}$ Department of Trade, Industry and Business, HUI Research and Dalarna University, Stockholm and Borlänge, Sweden \\ ${ }^{2}$ Department of Trade, Industry and Business, Dalarna University, Borlänge, Sweden \\ *Corresponding author: sven-olov.daunfeldt@hui.se
}

Received March 11, 2014; Revised March 18, 2014; Accepted March 27, 2014

\begin{abstract}
Purpose: This paper aims to extend and contribute to prior research on the association between company characteristics and choice of capital budgeting methods (CBMs). Design/methodology/approach: A multivariate regression analysis on questionnaire data from 2005 and 2008 is used to study which factors determine the choice of CBMs in Swedish listed companies. Findings: Our results supported hypotheses that Swedish listed companies have become more sophisticated over the years (or at least less unsophisticated) which indicates a closing of the theory-practice gap; that companies with greater leverage used payback more often; and that companies with stricter debt targets and less management ownership employed accounting rate of return more frequent. Moreover, larger companies used CBMs more often. Originality/value: The paper contributes to prior research within this field by being the first Swedish study to examine the association between use of CBMs and as many as twelve independent variables, including changes over time, by using multivariate regression analysis. The results are compared to a US and a continental European study.
\end{abstract}

Keywords: investment decisions, capital budgeting methods, project valuation, Swedish listed companies, CFO, sophisticated use

Cite This Article: Sven-Olov Daunfeldt, and Fredrik Hartwig, "What Determines the Use of Capital Budgeting Methods? Evidence from Swedish Listed Companies.” Journal of Finance and Economics, vol. 2, no. 4 (2014): 101-112. doi: 10.12691/jfe-2-4-1.

\section{Introduction}

Management's investment decision is pivotal for the success of any company and over the years a number of capital budgeting methods have evolved. The capital budgeting method choice is not arbitrary, and textbooks in financial management often recommend the net present value method, while discouraging the use of other techniques, such as the undiscounted payback method (Brealey and Myers, 2003; Lumby and Jones, 2003; Smart et al., 2004; Ross et al., 2005).

We use multivariate regression analysis on questionnaire data from 2005 and 2008 to study which factors determine the choice of capital budgeting methods in Swedish listed companies. Our first question is to what extent the recommended methods actually are used, i.e., is there a gap between theory and practice? Second, we investigate the average total use of capital budgeting methods. Do Swedish listed companies typically use just one method, or are two or even more used concurrently? Third, we examine what factors determine the use of the methods. For example, does size matter as suggested by Stanley and Block, (1984), Pike (1988, 1996), Graham and Harvey (2001), Sandahl and Sjögren (2003), and Brounen et al. (2004)? The relation between size and eleven other independent variables and eight capital budgeting methods are analysed. Finally we compare our results to studies of U.S. (Graham and Harvey, 2001) and continental European (Brounen et al., 2004) listed companies, which used data responding to the same questionnaire as used here.

Capital budgeting decisions are very important for financial managers, since they determine the choice of investment projects that will affect company value. The use of capital budgeting methods by U.S. and European listed companies has been studied extensively (e.g., besides those already mentioned, Pike, 1988, 1989, 1996; Pike and Sharp, 1989; Sangster, 1993; Block, 2007; Hermes et al., 2007). [1] There have also been some earlier studies of Sweden (Renck, 1966; Tell, 1978; Yard, 1987; Andersson, 1994; Segelod, 1995; Sandahl and Sjögren, 2003; Holmén and Pramborg, 2009; Hartwig, 2012).

The present study differs in one important respect from previous similar studies, the majority of which are based on purely descriptive statistics. [2] Most studies thus explore only use or non-use, or the frequency of use, of capital budgeting methods, and not the association between use and independent variables. When relationships between use and independent variables have been studied (e.g., Hartwig, 2012), only descriptive statistical methods such as correlation analysis and independent-samples t-tests are utilised, so the results cannot be interpreted causally [3]. 
Our results confirm previous findings that larger companies tend to use capital budgeting methods more often when deciding on investments. The choice of capital budgeting methods is also influenced by financial leverage, growth opportunities, dividend pay-out policies, the choice of target debt ratio, degree of management ownership, foreign sales, and the education and other individual characteristics of the CEO. The total use of capital budgeting methods is lower in Sweden than in the U.S. (Graham and Harvey, 2001), and continental Europe (Brounen et al., 2004).

The next section presents capital budgeting methods and explains why some of them are recommended by textbooks and others not. Data and descriptive statistics on the use of capital budgeting methods in Swedish listed companies are presented in Section 3. Section 4 then presents the empirical method and hypotheses to be tested. Results are presented and discussed in Section 5. Section 6 summarises and draws conclusions.

\section{The Use of Capital Budgeting Methods}

When evaluating investments, top managers can choose among many capital budgeting methods, some recommended in textbooks, others not. In accordance with Graham and Harvey (2001), we distinguish twelve capital budgeting methods (Table 1).

Table 1. Capital budgeting methods, recommended or not by textbooks

\begin{tabular}{|l|l|}
\hline Method & Recommended or not \\
\hline a) Net present value (NPV) & Recommended \\
\hline b) Internal rate of return (IRR) & Not recommended \\
\hline c) Annuity & Recommended \\
\hline d) Earnings multiple (P/E) & Not recommended \\
\hline e) Adjusted present value (APV) & Recommended \\
\hline f) Pay-back & Not recommended \\
\hline g) Discounted pay-back & Not recommended \\
\hline h) Profitability index & Recommended \\
\hline i) Accounting rate of return (ARR) & Not recommended \\
\hline j) Sensitivity analysis & Recommended \\
\hline k) Value-at-risk (VAR) & Recommended \\
\hline l) Real options & Recommended \\
\hline Method & Recommended or not \\
\hline a) Net present value (NPV) & Recommended \\
\hline b) Internal rate of return (IRR) & Not recommended \\
\hline c) Annuity & Recommended \\
\hline d) Earnings multiple (P/E) & Not recommended \\
\hline e) Adjusted present value (APV) & Recommended \\
\hline f) Pay-back & Not recommended \\
\hline g) Discounted pay-back & Not recommended \\
\hline h) Profitability index & Recommended \\
\hline i) Accounting rate of return (ARR) & Not recommended \\
\hline j) Sensitivity analysis & Recommended \\
\hline k) Value-at-risk (VAR) & Recommended \\
\hline l) Real options & Recommended \\
\hline
\end{tabular}

As noted, methods such as net present value (NPV) that discount cash flows, are often recommended in financial management textbooks. Brealey and Myers (2003), for example, has a chapter on "why net present value leads to better investment decisions than other criteria”. NPV is recommended since it incorporates all cash-flows that the investment generates as well as the time value of money.

Other methods, such as the internal rate of return (IRR) and pay-back methods are often criticised. IRR can be misleading when a choice must be made among mutually exclusive projects, and also because of so-called multiple rates of return (Ross et al., 2005), yet it is often used (Graham and Harvey, 2001; Sandahl and Sjögren, 2003; Brounen et al., 2004; Bennouna et al., 2010).

Pay-back methods do not consider the time value of money, and also ignores cash-flows that occur after the maximum pay-back time (as defined by management), yet it is also often used (Graham and Harvey, 2001; Sandahl and Sjögren, 2003; Brounen et al., 2004; Bennouna et al., 2010). Discounted pay-back does not ignore the time value of money, but still ignores cash-flows after the maximum pay-back point.

The earnings multiple or price/earnings (P/E) method is a variation on pay-back methods since it calculates how many years it will take until the initial investment (the share price) will be paid back by earnings. It considers earnings instead of cash-flows and only considers one earnings figure (instead of many), and again does not take the time value of money into consideration. On the other hand, this relative valuation method has the advantage of letting the more or less efficient capital market guide the decision.

The main disadvantage with ARR is (as the name suggests) that it uses accounting numbers (instead of cashflows) and again does not consider the time value of money (Ross et al., 2005). Note that management can affect accounting numbers positively through real actions even though their actions may have negative effects on long-term value (Graham et al. (2005).

In principal, sensitivity analysis has no drawbacks, and should be applied to see whether an investment will still be profitable if one or more variables are changed. Another method with no obvious drawbacks is real options. It has been suggested that the reason why many projects which look unprofitable at first glance are made nevertheless is that management explicitly or implicitly incorporated the possibility of making subsequent investments (conditioned on the current project) in the project evaluation.

Value-at-risk (VAR), measuring “...the worst loss over a target horizon that will not be exceeded with a given level of confidence” (Jorion, 2006; page viii), is a rather new method. A disadvantage is that is does not estimate how bad the loss might be if market conditions turn abnormal (such as happened widely in 2008-2009).

When the highest net present value per monetary unit of the initial outlay is calculated, a so-called profitability index has been established. A potential limitation is that, if applied carelessly and investment resources are constrained, it can give bad advice (Brealey and Myers, 2003).

APV adds the value of any financial side-effects of an investment to NPV, and should in principle have no drawbacks (Ross et al., 2005). The annuity method is also 
a variant of NPV. If you know the annuity of an investment, and how many years it should generate net cash-inflows or outflows, then you can easily calculate its NPV by discounting the annuity with the relevant weighted average cost of capital.

\section{Data and Descriptive Statistics}

To analyse what determines the choice of capital budgeting methods in Sweden, a questionnaire (Appendix 1) was sent in 2005 and 2008 to the CFOs of all Swedish companies listed on the Stockholm Stock Exchange. To facilitate a comparison between the surveys, the questions were the same as used by Graham and Harvey (2001) and Brounen et al. (2004). [4] If no executive had the title $\mathrm{CFO}$, then the questionnaire was sent to another senior executive (controller, treasurer, or CEO) responsible for financial management.

In 2005, the questionnaire was sent to 244 companies by postal mail three times, with response deadlines 8 January, 14 March, and 23 May. Non-respondents by the first deadline were contacted by phone to encourage them to respond. In the end, 112 questionnaires (45.9\%) were returned. However, seven were not useable and were dropped, leaving an adjusted response rate of $43.0 \%$.

In 2008, the questionnaire was sent to 249 companies by postal mail four times, with response deadlines 18 February, 10 March, 3 April, and 16 June. Again, nonrespondents by the first deadline were contacted by phone. In the end, 92 (36.9\%) questionnaires were returned. Four were not useable, leaving an adjusted response rate of $35.3 \%$. The total adjusted response rate for the two surveys was thus $39.1 \%$, compared to $9 \%$ for Graham and Harvey (2001) and 5\% for Brounen et al. (2004).

In simple probit analysis of the response rate the probability of response was statistically significantly higher for larger companies, and the probability to answer the survey was higher in 2005 compared to 2008. Industry classification, P/E-ratio, degree of leverage, and dividend pay-out level did not have statistically significant effects on the probability of response (Table A1 in Appendix 2).

The questionnaire made clear that questions regarding capital investment referred to all non-routine capital investments accepted or rejected at group/parent-company level. The reason for this framing was that otherwise, i.e., if questions were taken to refer to all investments in the company (including investments accepted or rejected at subsidiary level), then the respondents probably would not be able to give credible answers.

\subsection{Dependent Variables}

The questionnaire (Appendix 1) consists of three main questions regarding the use of capital budgeting and costof-capital estimation techniques. [5] Data from question one, "How often do you use the following capital budgeting methods (on a scale of 0 to 4 , with $0=$ never and 4 = always)?”, was used to construct our dependent variables. The capital budgeting methods asked about were:
a). Net-present value (NPV)
b). Internal rate of return (IRR)
c). Annuity
d). Earnings multiple

e). The adjusted present value (APV)

f). Pay-back

g). Discounted pay-back

h). Profitability index

i). Accounting rate of return (ARR)

j). Sensitivity analysis

k). Value-at-risk (VAR)

l). Real options

The number and share of respondents reporting that they occasionally or never use or frequently or always use each method are reported in Table 2. Annuity, adjusted present value (APV), value-at-risk, and real options were far less used than the other methods. We excluded them from further analysis as not providing sufficient variation to analyze.

Table 2. Number and proportion of companies that used each capital budgeting Method never or occasionally (0-2) vs frequently or always (3-4)

\begin{tabular}{|l|ll|ll|}
\hline Capital budgeting method & $0-2$ & $\%$ & $3-4$ & $\%$ \\
\hline (a) NPV & 75 & $38.86 \%$ & 118 & $61.14 \%$ \\
(b) IRR & 135 & $69.95 \%$ & 58 & $30.05 \%$ \\
(c) Annuity & 187 & $96.89 \%$ & 6 & $3.11 \%$ \\
(d) Earnings multiple approach & 139 & $72.02 \%$ & 54 & $27.98 \%$ \\
(e) APV & 180 & $93.26 \%$ & 13 & $6.74 \%$ \\
(f) Pay-back & 88 & $45.60 \%$ & 105 & $54.40 \%$ \\
(g) Discounted pay-back & 160 & $82.90 \%$ & 33 & $17.10 \%$ \\
(h) Profitability index & 169 & $87.56 \%$ & 24 & $12.44 \%$ \\
(i) ARR & 147 & $76.17 \%$ & 46 & $23.83 \%$ \\
(j) Sensitivity analysis & 106 & $54.92 \%$ & 87 & $45.08 \%$ \\
(k) VAR & 180 & $93.26 \%$ & 13 & $6.74 \%$ \\
(l) Real options & 189 & $97.93 \%$ & 4 & $2,07 \%$ \\
\hline
\end{tabular}

The recommended methods used frequently or always by the most listed companies in Sweden were the net present value (61\%) and sensitivity analysis (45\%), but not recommended pay-back method was used frequently or always by $54 \%$ of the respondents.

Mean values, standard deviations, and differences in mean values for the most used capital budgeting methods in 2005 and 2008 are reported in Table 3. Higher mean values indicate more extensive use of the method.

Table 3. Mean values, standard deviations, and differences in mean values for the most used capital budgeting methods in 2005 and 2008

\begin{tabular}{|c|c|c|c|c|c|}
\hline Dependent variable & $\begin{array}{l}2005 \\
\text { Mean }\end{array}$ & Sd & $\begin{array}{l}2008 \\
\text { Mean }\end{array}$ & Sd & Difference \\
\hline (a) NPV & 2.50 & 1.38 & 2.55 & 1.38 & 0.05 \\
\hline (b) IRR & 1.57 & 1.58 & 1.27 & 1.45 & $-0.30 * * *$ \\
\hline (d) Earnings multiple & 1.36 & 1.61 & 1.41 & 1.57 & 0.05 \\
\hline (f) Pay-back & 2.39 & 1.41 & 2.20 & 1.47 & -0.19 \\
\hline (g) Discounted pay-back & 1.08 & 1.42 & 0.74 & 1.31 & $-0.34 * * *$ \\
\hline (h) Profitability index & 0.69 & 1.26 & 0.72 & 1.20 & 0.03 \\
\hline (i) ARR & 1.14 & 1.55 & 1.05 & 1.45 & -0.10 \\
\hline (j) Sensitivity analysis & 1.92 & 1.63 & 2.05 & 1.53 & 0.12 \\
\hline
\end{tabular}

Note: $* * *$ indicates that the difference is statistically significant at the $1 \%$ level.

The differences between 2005 and 2008 are small, usually not significantly different from zero. The biggest differences are that IRR and the discounted pay-back 
(both not recommended) were less used in 2008 than in 2005.

Figure 1 compares the total use of capital budgeting methods by listed Swedish companies (287\%) to U.S. results (413\%, Graham and Harvey, 2001) and continental European results (308-388\%, Brounen et. al, 2004). Total use was calculated as the sum of column 3 on Table 2 , and was thus much lower in Sweden compared to the U.S. and continental Europe.

The differences between Sweden and the U.S. or continental Europe are surprising since our data only is from listed companies, which should mean more use of capital budgeting methods (since listed companies are presumably more sophisticated, gathering more information before making investments).

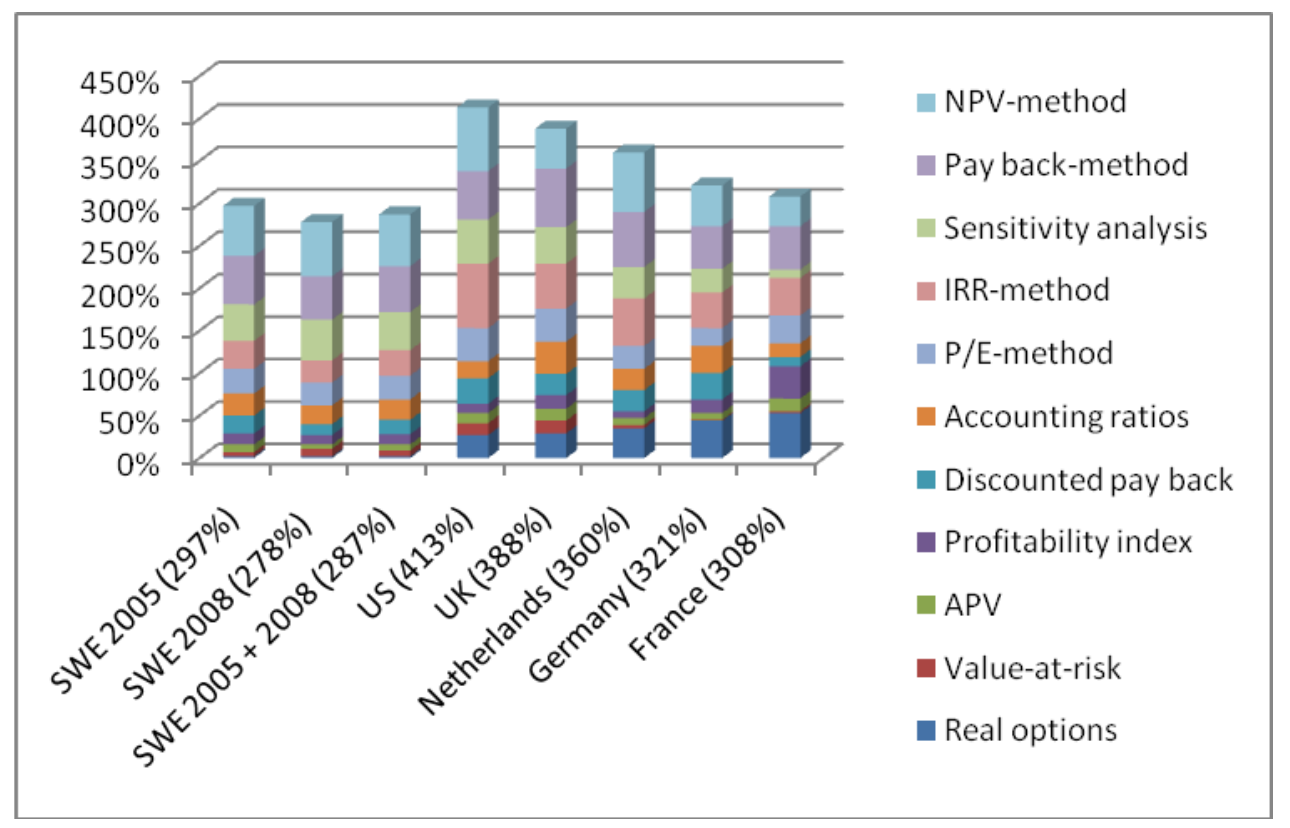

Figure 1. The total stated use of capital budgeting techniques in Swedish

Figure 2 compares use of each method across countries. A recommended method that is very uncommon in Sweden compared to the U.S. and continental Europe is incorporation of real options. But other recommended methods such as NPV and sensitivity analysis were used more frequently by Swedish listed companies than by most continental European ones.

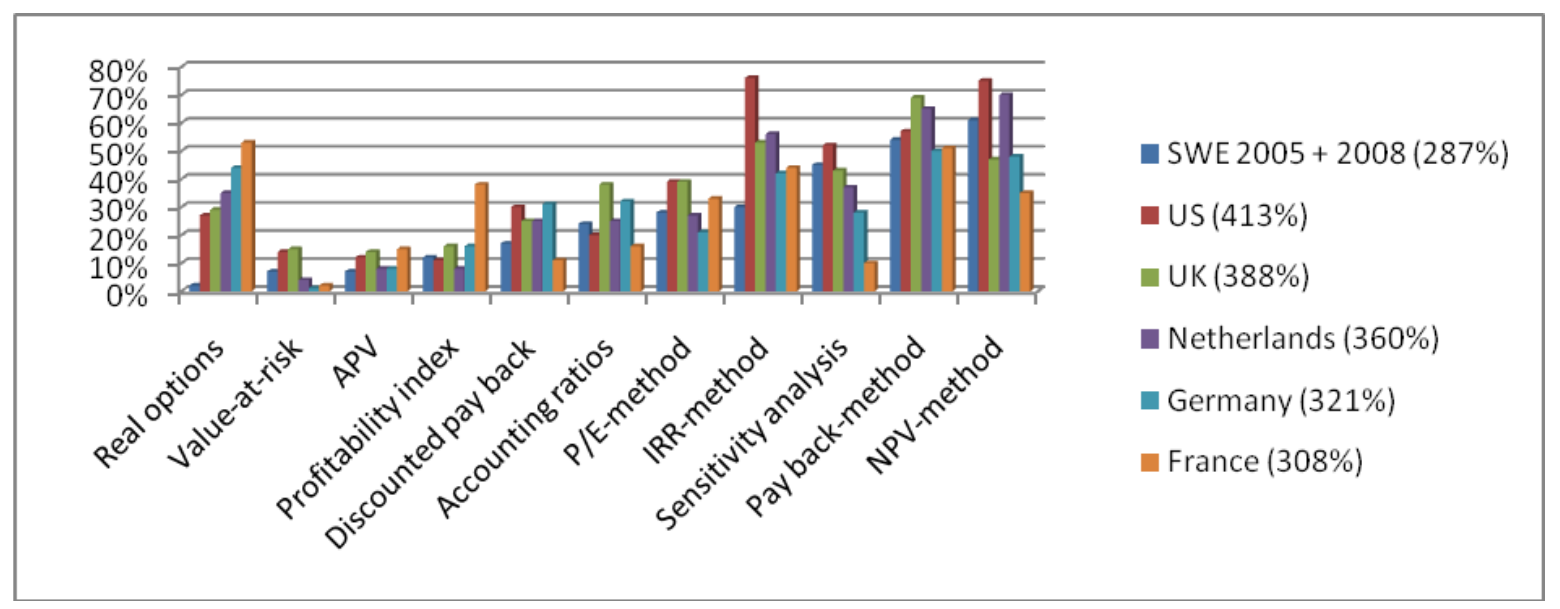

Figure 2. The stated use of different capital budgeting techniques in Swedish companies compared to companies in the US and continental Europe

\subsection{Independent variables}

We use information on company size, company leverage, growth opportunities, dividend payout levels, industry classification (manufacturing or not), target debt ratio, proportion of foreign sales, proportion of shares owned by the management, changes over time (a year dummy), as well as the age, educational attainment and the tenure of the CEO to analyze which variables influence the reported use of capital budgeting methods. Definitions, means, and standard deviations are presented in Table 4. The variables included are further discussed in Section 4.

Data on target debt-ratio, proportion of foreign sales, proportion of shares owned by management, and characteristics of the CEO are obtained from the questionnaire, while data on company size, growth opportunities, leverage, industry classification, and dividend payments come from Datastream. [6] Data was intentionally obtained from Datastream for 2004 and 2007 to prevent a possible endogeneity problem, since previous year's values are predetermined. 
Company size is approximated by revenues adjusted for inflation using the Swedish Consumer Price Index published by Statistics Sweden. Growth opportunities are proxied by the price-earnings $(\mathrm{P} / \mathrm{E})$ ratio because high $\mathrm{P} /$ E-ratios are thought to mean that the capital market expects the company to have high future growth, and leverage is measured by the debt-to-asset ratio. Even though it may be the CFO who chooses the capital budgeting method, questions regarding the CEO were asked since the CFO is seen as the CEO's agent.

Table 4. Means, standard deviations, definitions and sources of independent variables

\begin{tabular}{|c|c|c|c|}
\hline $\begin{array}{l}\text { Independent } \\
\text { variable }\end{array}$ & $\begin{array}{l}\text { Mea } \\
\mathrm{n}\end{array}$ & SD & Definition and source \\
\hline SIZE (millions) & 13.1 & 31.8 & Deflated revenues in SEK. Source: Datastream. \\
\hline LEVERAGE & 0.21 & 0.19 & Total debt to total assets ratio. Source: Datastream. \\
\hline DIVPAY & 0.24 & 0.96 & Dividend pay-out ratio. Dividend divided by net income. Source: Datastream. \\
\hline GROWTH & 9.20 & 66.44 & P/E ratio. Source: Datastream. \\
\hline$D M A N$ & 0.40 & 0.49 & Dummy taking the value one if the company could be classified as manufacturing. Source: Datastream. \\
\hline TARGET_DEBT & 2.24 & 1.02 & Whether the company had no (1) or a strict (4) target debt-ratio. Source: Survey (question 9). \\
\hline FSALES & 3.30 & 0.98 & $\begin{array}{l}\text { The proportion of total sales that took place outside Sweden, ranging from } 0 \% \text { (1) to > 50\% (4). Source: } \\
\text { Survey (question 12) }\end{array}$ \\
\hline MAN_OWN & 1.38 & 0.93 & $\begin{array}{l}\text { Share of the company that would be owned by the top three officers if all options had been exercised, } \\
\text { ranging from } \\
<5 \% \text { (1) to }>20 \% \text { (4). Source: Survey (question 12). }\end{array}$ \\
\hline CEO_AGE & 2.43 & 0.73 & Age of the CEO ranging from < 40 years (1) to > 60 years (4). Source: Survey (question 12 ). \\
\hline CEO_EDUC & 1.82 & 0.84 & $\begin{array}{l}\text { Dummy taking the value one if the CEO had a Masters inBusiness and/or Economics. Source: Survey } \\
\text { (question 12). }\end{array}$ \\
\hline CEO_TENURE & 1.61 & 0.75 & $\begin{array}{l}\text { Number of years the CEO had been CEO in the company, ranging from }<4 \text { year (1) to }>9 \text { year (3). } \\
\text { Source: Survey (question 12). }\end{array}$ \\
\hline DYEAR & 0.46 & 0.50 & Dummy, taking the value one in 2008, zero in 2005. \\
\hline
\end{tabular}

The relationships among the independent variables were investigated using Pearson product-moment correlation coefficients (Table A2 in Appendix 3), with multicollinearity found to be limited. The highest correlation coefficient was 0.48 , while most were far lower.

\section{Empirical Method and Hypotheses}

To analyze what determines the reported use of capital budgeting method, the following equation is estimated using ordinary least square (OLS):

$$
\begin{aligned}
\text { CBT }_{\text {it }}^{\mathrm{j}} & =\alpha_{0}+\alpha_{1} \text { SIZE }_{\mathrm{it}}+\alpha_{2} \text { GROWTH }_{\mathrm{it}} \\
& +\alpha_{3} \text { LEVERAGE }_{\mathrm{it}}+\alpha_{4} \text { TARGET }_{-} \text {DEBT }_{\mathrm{it}} \\
& +\alpha_{5} \text { DIVPAY }_{\mathrm{it}}+\alpha_{6} \text { FSALES }_{\mathrm{it}} \\
& +\alpha_{7} \text { MAN_OWN }_{\mathrm{it}}+\alpha_{8} \text { CEOEDUC }_{\mathrm{it}} \\
& +\alpha_{9} \text { CEOAGE }_{\mathrm{it}}+\alpha_{10} \text { CEOTENURE }_{\mathrm{it}} \\
& +\alpha_{11} \text { DMAN }_{\mathrm{it}}+\alpha_{12} \text { DYEAR }_{\mathrm{t}}+\mathrm{e}_{\mathrm{it}}
\end{aligned}
$$

where $C B T_{i t}^{j}$ is the reported use of capital budgeting method $j(j=1,2, \ldots, 8)$ by company $i(i=1,2, \ldots 152)$ during year $t(t=2005,2008)$. As noted earlier, $S I Z E_{i t}$ is deflated revenues (for company $i$ during year $t$ ); LEVERAGE is the debt-to-assets ratio; GROWTH is the price-earnings ratio; TARGET_DEBT reflects a survey question whether the company had a strict or flexible debt target; MAN_OWN reflects a survey question on the proportion of shares owned by management; CEOEDUC reflects the educational attainment of the CEO; CEOAGE reflects CEO's age; CEOTENURE reflects how long the CEO has had that position; DMAN is a dummy taking the value one if the company can be classified as a manufacturing company, and zero otherwise; DIVPAY is company i's dividend payout ratio; FSALES reflects a survey question on the proportion of foreign sales; and DYEAR is a dummy taking the value zero in 2005, and one in 2008.

When estimating Equation (1), we expect size to be related to the use of recommended capital budgeting methods (Pike, 1988, 1996; Graham and Harvey, 2001;
Sandahl and Sjögren, 2003; Brounen et al., 2004; Verbeeten, 2006) because large companies tend to deal with larger projects, making the use of more sophisticated methods less costly (Payne et al., 1999; Hermes et al., 2007).

We expect high leverage to be related to the use of the non-recommended pay-back method, which has been found to be positively associated with economic uncertainty (Schall and Sundem, 1980; Binder and Chaput, 1996). Simpler rules (such as pay-back) can be more attractive in an uncertain setting, since the costs of accurately estimating the inputs for more complicated discounting-based calculations are higher (Binder and Chaput, 1996). An alternative explanation as to why high leverage companies might be expected to use pay-back more often is that they are under more financial pressure and might therefore feel a need to find investments that quickly "pay back" the initial investment.

We expect growth companies to use two recommended methods more frequently. First, finance textbooks teach that IRR should not be used to rate mutually exclusive projects [7], which growth companies might have more of than mature companies. Growth companies might also be more likely to calculate the profitability index, because if they have more potential new investment projects [8], and thus reject more, it would be important that the accepted ones give the highest possible NPV per unit invested, and the only way to establish that is through calculating the profitability index.

We expect companies with strict debt targets to use the non-recommended ARR method more often. Companies which are closer to violating accounting-based debt covenants have been found more likely to choose income enhancing accounting solutions which reduce the risk of “costly” technical default (Watts and Zimmerman, 1990). The same thing might happen with regard to "internal debt covenants" (i.e., debt targets); the higher the "cost" of violating the accounting based debt target, the more the company might consider how an investment would affect accounting numbers. Companies with a stricter target might thus tend to consider an investment's impact on the 
accounting debt-ratio to a higher extent (so that the target debt-ratio is not "violated”). The accounting rate of return indicates how an investment is expected to affect the debt ratio, and could therefore be employed more extensively in strict debt-target companies.

We expect companies with greater management ownership to use recommended methods more often. Ownership structure can have an impact on managerial decisions and company performance (Warfield et al., 1995; Klassen, 1997), and companies with greater managerial ownership have been found to be less likely to experience financial distress (Donker et al., 2009), perhaps because managers then have more to lose if the company goes bankrupt. Management ownership may thus reduce management opportunism and increase use of recommended capital budgeting methods.

On the other hand, with greater separation of ownership (principals) and management (agents) incentives can arise for managers to pursue non-value maximising behaviour (Jensen and Meckling, 1976). To remedy this, contracts often stipulate that management's remuneration should be based on accounting numbers. Top managers' discretion over both business activities and accounting choices makes it possible for them to manage earnings upwards, to maximise their own bonus payments (Healy, 1985). Managers can thus take either accounting actions or realactions to manage earnings or other accounting figures (Dechow and Skinner, 2000). [9] Managers focused on meeting accounting figures might reject a profitable investment (with positive NPV) if the calculated accounting rate of return is too low. [10] Graham et al. (2005) showed that top management was willing to sacrifice long-term value just to meet accounting targets. [11] We believe that this focus on accounting numbers is more profound in companies with low levels of management ownership, and we therefore expect that management owned companies use ARR less frequent.

We expect more educated and younger CEOs to use recommended methods (Hermes et al., 2007), with which they might be more familiar and to which they might be more open. We also expect new CEOs to use more "socially acceptable" (often recommended methods), whereas CEOs with more company-specific experience might be more relaxed and choose simpler methods, perhaps viewing them as "good enough". But more experienced CEOs might choose more recommended methods if taught their value by experience.

There might also be industry-specific differences when it comes to the use of methods. We expect manufacturing companies to use more recommended methods because they are often larger, more capital intensive with higher sunk costs.

We expect that companies with a higher dividend payout ratio use profitability index calculations methods less often because (apart from expectations about future positive cash flows and profits) a higher dividend payout indicates that the company is liquid, making capital rationing less likely.

We expect a positive relation between foreign sales, presumably reflecting a higher proportion of foreign investments, with attendent currency and political risks, and use of sensitivity analysis. Moreover, we expect that foreign sales is positively associated with the pay-back method. [12] Holmén and Pramborg (2009) documented that the use of the payback method increases with political risk. The suggested reason for the observed positive relation (between political risk and the pay-back method) is that political risk is difficult to estimate (i.e. rendering high deliberation costs).

Finally, we expect more use of recommended methods in 2008 than in 2005, because the use of capital budgeting methods has become more sophisticated over time (Klammer and Walker, 1984; Pike, 1996; Ryan and Ryan, 2002; Sandahl and Sjögren, 2003;Singh et al., 2012; Bennouna et al., 2010).

\section{Results and Discussion}

Company size has generally been positively correlated with the use of recommended capital budgeting methods (Graham and Harvey, 2001; Brounen et al., 2004). We find that large companies use NPV (recommended), IRR (not recommended), pay-back (not recommended), and sensitivity analysis (recommended) more than small companies; results for the other methods were smaller and less statistically significant (Table 5).

Contrary to our results, Graham and Harvey (2001) found a statistically significant negative relation between size and pay-back in particular in the U.S., while Brounen et al. (2004) found no statistically significant relation between size and pay-back in any of their four continental European countries (Germany, France, Netherlands, and UK).

Contrary to our expectations, Swedish listed companies with higher growth opportunities (which we measured by their P/E ratio) used IRR (not recommended) more often but profitability index (recommended) less often. Possibly the $\mathrm{P} / \mathrm{E}$ ratio is a bad proxy for growth opportunities, or maybe "growth companies" actually have or assess fewer investment opportunities than do mature companies.

High-leverage companies employed the pay-back method more frequent, confirming our hypothesis that companies with a high level of financial risk are more likely to use the non-reommended, and non-discounting based, pay-back method. However, high leveraged companies also had a tendency to utilise NPV and IRR, which both are discounting based methods, more extensively than low leveraged companies, supporting results presented previously by Graham and Harvey (2001).

Confirming our expectations, companies with stricter debt targets used ARR (not recommended) more often. Companies with stricter debt targets also employed the profitability index (recommended) more, a result also found by Graham and Harvey (2001).

Contrary to what we expected, companies with a higher dividend pay-out level utilised profitability index more extensively, as well as using IRR (not recommended) and sensitivity analysis (recommended) more. Companies with more foreign sales used profitability index less. Moreover, foreign sales was not significantly positively related to the use of the pay-back method. The latter result thus fails to support the findings in Holmén and Pramborg (2009).

Management-owned companies used ARR (not recommended) and sensitivity analysis (recommended) less often, supporting previous findings that ownership structure influence management decisions (Gul et al., 2002; Hutchinson and Leung, 2007; Siregar and Utama, 
2008). Management-owned companies might use ARR because of greater goal-congruence between agent and principal, with owners more interested in the economic than accounting returns of an investment. There may also be other (preferred) communicative and monitoring tools than formal accounting numbers in companies with high management (Eng and Mak, 2003), making an investment's impact on accounting rate of return not as important.

Table 5. Estimation results

\begin{tabular}{|c|c|c|c|c|c|c|c|c|c|}
\hline Variable & & (a) NPV & (b) IRR & (d) EM & (f) PB & (g) DPB & (h) PI & (i) ARR & (j) SA \\
\hline \multirow[t]{2}{*}{ SIZE } & Coef. & $0,00598 * *$ & $0,00975 * * *$ & 0,00261 & $0,00623 *$ & 0,00131 & $-0,00146$ & $-0,00172$ & $0,00742 * *$ \\
\hline & t-value & 2.28 & 2.72 & 0.85 & 1.94 & 0.38 & -0.75 & -0.46 & 2.61 \\
\hline \multirow[t]{2}{*}{ GROWTH } & Coef. & 0,0033 & $0,0034 * *$ & $-0,0004$ & 0,0010 & 0,0015 & $-0,0021 * * *$ & 0,0016 & 0,0022 \\
\hline & t-value & 1.64 & 2.00 & -0.27 & 1.06 & 1.12 & -2.76 & 1.59 & 1.28 \\
\hline \multirow[t]{2}{*}{ LEVERAGE } & Coef. & $1,15^{*}$ & $1,52 * *$ & $-0,34$ & $1,37 * *$ & 0,59 & $-0,11$ & 0,45 & 0,34 \\
\hline & t-value & 1.78 & 2.32 & -0.48 & 2.16 & 0.89 & -0.17 & 0.61 & 0.49 \\
\hline \multirow[t]{2}{*}{ TARGET_DEBT } & Coef. & 0,02 & 0,13 & 0,00 & 0,12 & $-0,06$ & $0,16^{*}$ & $0,30 * *$ & 0,11 \\
\hline & t-value & 0.17 & 1.12 & 0.04 & 1.06 & -0.60 & 1.69 & 2.45 & 0.89 \\
\hline \multirow[t]{2}{*}{$\overline{D I V P A Y}$} & Coef. & $-0,12$ & $-0,35 * * *$ & $-0,04$ & $-0,01$ & $-0,19$ & $0,13^{*}$ & 0,05 & $-0,20 *$ \\
\hline & t-value & -1.13 & -3.40 & -0.24 & -0.15 & -1.08 & 1.73 & 0.41 & -1.88 \\
\hline \multirow[t]{2}{*}{ FSALES } & Coef. & 0,06 & 0,06 & $-0,05$ & 0,18 & 0,30 & $-0,27 * *$ & $-0,09$ & 0,20 \\
\hline & t-value & 0.54 & 0.49 & -0.32 & 1.41 & 0.28 & -2.16 & -0.70 & 1.41 \\
\hline \multirow[t]{2}{*}{ MAN_OWN } & Coef. & $-0,03$ & $-0,04$ & $-0,24$ & $-0,06$ & $-0,11$ & 0,03 & $-0,26 * *$ & $-0,33 * *$ \\
\hline & t-value & -0.18 & -0.25 & -1.59 & -0.45 & -0.76 & 0.30 & -2.16 & -2.04 \\
\hline \multirow[t]{2}{*}{ CEO_EDUC } & Coef. & 0,01 & $0,36 * *$ & 0,22 & 0,17 & $0,29 * *$ & $-0,09$ & 0,17 & 0,25 \\
\hline & t-value & 0.08 & 2.34 & 1.28 & 1.04 & 2.14 & -0.46 & 1.09 & 1.42 \\
\hline \multirow[t]{2}{*}{ CEO_AGE } & Coef. & $-0,04$ & $-0,04$ & $-0,13$ & $-0,13$ & 0,11 & $-0,05$ & $0,34 *$ & $-0,32 *$ \\
\hline & t-value & -0.22 & -0.22 & -0.63 & -0.79 & 0.67 & -0.32 & 1.95 & -1.68 \\
\hline \multirow[t]{2}{*}{ CEO_TENURE } & Coef. & $-0,07$ & 0,25 & 0,05 & 0,11 & 0,08 & $-0,10$ & $-0,13$ & $0,33^{*}$ \\
\hline & t-value & -0.37 & 1.43 & 0.25 & 0.63 & 0.49 & -0.72 & -0.80 & 1.78 \\
\hline \multirow[t]{2}{*}{$\overline{D M A N}$} & Coef. & $-0,18$ & 0,25 & $-0,47^{*}$ & 0,14 & 0,25 & $-0,47 * *$ & $-0,13$ & $-0,14$ \\
\hline & t-value & -0.73 & 1.08 & -1.69 & 0.59 & 1.11 & -2.37 & -0.59 & -0.51 \\
\hline \multirow[t]{2}{*}{ DYEAR } & Coef. & $-0,13$ & $-0,82 * * *$ & $-0,31$ & $-0,41$ & $-0,64 * * *$ & $-0,05$ & $-0,23$ & $-0,33$ \\
\hline & t-value & -0.54 & -3.23 & -1.08 & -1.55 & -2.77 & -0.24 & -0.91 & -1.18 \\
\hline \multirow[t]{2}{*}{ CONSTANT } & Coef. & $2,38 * * *$ & 0,14 & $2,16 * *$ & 1,154 & 0,32 & 1,88 & 0,28 & $1,52^{*}$ \\
\hline & t-value & 3.61 & 0.17 & 2.43 & 1.56 & 0.50 & 3.07 & 0.38 & 1.80 \\
\hline $\mathrm{R}^{2}$ & & 0.08 & 0.19 & 0.08 & 0.10 & 0.08 & 0.15 & 0.15 & 0.12 \\
\hline
\end{tabular}

The reduced use of sensitivity analysis (recommended) by management-owned companies could be interpreted as contradicting the argument that owner-managers would tend to use more sophisticated methods. But it could also be that non-owner managers estimate how sensitive ARR (rather than, say NPV) is to changes in the assumptions (thus not necessarily leading to increased shareholder value). And it could be that non-owner managers make ARR estimations "internally" (to see how the accounting numbers are affected), but show NPV-based sensitivity analyses to other executives/board members to legitimise their investment choice (Dowling and Pfeffer, 1975; Gray et al., 1996).

As expected, older CEOs used the accounting rate of return (not recommended) more often, but sensitivity analysis (recommended) less. On the other hand, CEOs with long tenure used sensitivity analysis more often. Contrary to expectations, more educated CEOs used both IRR (not recommended) and discounted pay-back (not recommended) more. A positive association between CEO education and use of IRR has also been found in the U.S. (Graham and Harvey, 2001), and the Netherlands, Germany and France, though not in the UK (Brounen et al. 2004).

Confirming our expectations, manufacturing companies used earnings multiple approach (not recommended) less, but also used profitability index (recommended) less, contradicting our expectations. Finally, IRR (not recommended) and discounted pay-back (not recommended) were used less often in 2008 than in 2005. Thus, the use of recommended methods may not have increased, but the use of non-recommended methods seems to have decreased.

\section{Summary and Conclusions}

We analysed what determined the use of capital budgeting methods in Swedish listed companies in 2005 and 2008. Data on the use of capital budgeting methods were obtained from a survey sent out to all Swedish companies listed on the Stockholm Stock Exchange. The survey is a replica of that used by Graham and Harvey (2001) and Brounen et al. (2004).

Previous studies have found size to be positively correlated with the use of some capital budgeting methods. However, most of these studies were based on descriptive methods such as correlation analysis and independent sample t-tests, which are not sufficient to establish causality. Using multivariate regression analysis, we found that large companies used net present value (recommended), internal rate of return (not recommended), pay-back (not recommended), and sensitivity analysis (recommended) more than small companies.

Other company-specific variables that seemed to influence the choice of method were growth opportunities of the company, leverage, the dividend pay-out ratio, target debt ratio, the degree of management ownership, foreign sales, industry and individual characteristics of the CEO. Our results supported hypotheses that Swedish listed companies have become more sophisticated over the years (or at least less unsophisticated); that companies with greater leverage used payback more; and that companies with stricter debt targets and less management ownership employed ARR more.

Surprisingly, companies with more educated CEOs used non-recommended methods such as IRR and discounted pay-back more than others. Possibly it is the characteristics of the CFO (not the CEO) that influence the choice of capital budgeting methods, which is thus a topic for further study. 
The reported use of capital budgeting methods was compared to U.S. and continental European studies. Total use of capital budgeting methods was higher in the U.S. (Graham and Harvey, 2001) and in continental Europe (Brounen et al., 2004) than in Sweden. This is surprising since data only is from listed companies, whereas both non-listed as well as listed companies were included in Graham and Harvey (2001) and Brounen et al. (2004). It can be assumed that listed companies are more sophisticated, gathering more information before making investments, which should mean more extensive use of capital budgeting methods.

Our study measured only reported use of capital budgeting methods, not actual use; i.e., we measured beliefs rather than actions. We cannot be sure what methods were actually used. But our survey nevertheless enabled a broad and rich overview of capital budgeting methods in Sweden, facilitating comparisons between countries and over time.

\section{Notes:}

1. The use of capital budgeting method has also been studied in other parts of the world, including Australia (Truong et al., 2008) and Asia (Kester et al., 1999; Kwong, 1986), but not to the same extent.

2. Hermes et al. (2007) is an exception, but was mainly interested in exploring country differences in the use of capital budgeting methods. Silvola (2006) is another exception, but only investigated whether small high-tech companies in Finland used other capital budgeting methods than did small companies in other industries. Finally, Holmén and Pramborg (2009) used logit regression to investigate whether the use of capital budgeting methods for foreign direct investments was related to the political risk in the host country.

3. Hartwig (2012) found a positive correlation between company size and use of the net present value method, with two possible non-causal explanations: (i) the use of a more sophisticated methods such as net present value could lead to better growth opportunities and thus to larger companies; or (ii) an omitted variable, such as CEO education, could cause both better growth opportunities and choice of capital budgeting method.

4. Graham and Harvey (2001) - declared the best paper published in the Journal of Financial Economics in 2001 is very often referred to in both academic journals and textbooks.

5. The questionnaire also includes questions regarding financing decisions. Those answers are analysed in a separate study.

6. In a few instances, when data was not available from Datastream, it was obtained directly from the company.

7. Investment projects are said to be mutually exclusive if only one could be accepted.

8. In mature companies, a larger portion of the total capital investment budget might consist of reinvestments. Since the business activities to a higher extent are given in a mature company (at least in the short to medium run), one could expect that the number of potential investment projects are fewer.

9. "Real actions" refers to actions that affect cash flows.
10. Calculating accounting rate of return on investments gives an approximate estimate of how accounting ratios (like return on assets) would be affected.

11. The fact that top managers in general do not believe that the capital market is able to see through managed financial statements (Collison et al., 1996; Tzovas, 2006), is probably a contributing factor as to why they focus on accounting numbers.

12. Naturally, we do not know how much political risk companies with foreign sales (which is a proxy for foreign investments) are exposed to. It is, however, probable that companies with a lower proportion of foreign sales/investments, all other things held constant, are exposed to less political risk.

\section{References}

[1] Andersson, B. (1994), Investeringar och Energianvändning, Ph.D. Dissertation, University of Gothenburg, Gothenburg.

[2] Bennouna, K., Meredith, G.G. and Marchant, T. (2010), "Improved capital budgeting decision making: Evidence from Canada”, Management Decision, Vol. 48 No. 2, pp. 225-247.

[3] Binder, J.J. and Chaput, J.S. (1996), "A positive analysis of corporate capital budgeting practices", Review of Quantitative Finance and Accounting, Vol. 6 No. 3, pp. 245-257.

[4] Block, S. (2007), "Are real options actually used in the real world?”, The Engineering Economist, Vol. 52 No. 3, pp. 255-267.

[5] Brealey, R.A. and Myers, S.C. (2003), Principles of Corporate Finance, International Edition, 7th ed, McGraw-Hill, New York.

[6] Brounen, D., De Jong, A. and Koedijk, K. (2004),“Corporate finance in Europe: Confronting theory with practice", Financial Management, Vol. 33 No. 4, pp. 71-101.

[7] Collison, D.J., Grinyer, J.R. and Russel, A. (1996), "U.K. managers' decisions and their perceptions of capital markets", Journal of International Accounting, Auditing and Taxation, Vol. 5 No. 1, pp. 39-52.

[8] Dechow, P.M. and Skinner, D.J. (2000), "Earnings management: Reconciling the views of accounting academics, practitioners, and regulators”, Accounting Horizons, Vol. 14 No. 2, pp. 235-250.

[9] Donker, H., Santen, B. and Zahir, S. (2009), "Ownership structure and the likelihood of financial distress in the Netherlands", Applied Financial Economics, Vol. 19 No. 21, pp. 1687-1696.

[10] Dowling J. and Pfeffer, J. (1975), "Organizational legitimacy: Social values and organizational behaviour", Pacific Social Review, Vol. 18 No. 1 pp. 122-136.

[11] Eng, L.L. and Mak, Y.T. (2003), “Corporate governance and voluntary disclosure”, Journal of Accounting and Public Policy, Vol. 22 No. 4, pp. 325-345.

[12] Graham, J.R. and Harvey, C.R. (2001), "The theory and practice of corporate finance: Evidence from the field", Journal of Financial Economics, Vol. 60 Nos. 2-3, pp. 187-243.

[13] Graham, J.R., Harvey, C.R. and Rajgopal, S. (2005), "The economic implications of corporate financial reporting", Journal of Accounting and Economics, Vol. 40 Nos. 1-3, pp. 3-73.

[14] Gray, R., Owen, D. and Adams, C. (1996), Accounting and Accountability. Changes and Challenges to Corporate and Environmental Reporting, Prentice-Hall, London.

[15] Gul, F.A., Lynn, S.G. and Tsui, J.S.L. (2002), “Audit quality, management ownership, and the informativeness of accounting earnings", Journal of Accounting, Auditing and Finance, Vol. 17 No. 1, pp. 25-49.

[16] Hartwig, F. (2012), "The use of capital budgeting and cost of capital estimation methods in Swedish-Listed Companies", Journal of Applied Business Research, Vol. 28 No. 6, pp. 14511476.

[17] Healy, P.M. (1985), "The effect of bonus schemes on accounting decisions", Journal of Accounting and Economics, Vol. 7 Nos. 1-3, pp. 85-107.

[18] Hermes, N., Smid, P. and Yao, L. (2007), "Capital budgeting practices: A comparative study of the Netherlands and China", International Business Review, Vol. 16 No. 5, pp. 630-654.

[19] Holmén, M. and Pramborg, B. (2009), "Capital budgeting and political risk: Empirical evidence”, Journal of International 
Financial Management and Accounting, Vol. 20 No. 2, pp. 105134.

[20] Hutchinson, M. and Leung, S. (2007), “An investigation of factors influencing the association between top management ownership and earnings management”, Journal of Contemporary Accounting and Economics, Vol. 3 No. 2, pp. 130-153.

[21] Jensen, M.C. and Meckling, W.H. (1976), "Theory of the firm: Managerial behaviour, agency costs and ownership structure", Journal of Financial Economics, Vol. 3 No. 4, pp. 305-360.

[22] Jorion, P. (2006), Value at Risk - The New Benchmark for Managing Financial Risk, 3rd ed, McGraw-Hill, New York.

[23] Kester, G.W., Chang, R.P., Echanis, E.S., Haikal, S., Isa, M.M., Skully, M.T., Tsui, K.S. and Wang, C.J.(1999), “Capital budgeting practices in the Asia-Pacific region: Australia, Hong Kong, Indonesia, Malaysia, Philippines, and Singapore”, Financial Practice and Education, Vol. 9 No. 1, pp. 25-33.

[24] Klammer, T.P. and Walker, M.C. (1984), "The continuing increase in the use of sophisticated capital budgeting techniques", California Management Review, Vol. 27 No. 1, pp. 137-148.

[25] Klassen, K.J. (1997), "The impact of inside ownership concentration on the trade-off between financial and tax reporting", The Accounting Review, Vol. 72 No. 3, pp. 455-474.

[26] Kwong, H.C.(1986), "The sophistication of capital budgeting in Malaysian companies”, Omega, Vol. 14 No. 2, pp. 175-181.

[27] Lumby, S. and Jones, C. (2003), Corporate Finance: Theory and Practice, 7th ed, Thomson Learning, London.

[28] Pike, R. (1988),"An empirical study of the adoption of sophisticated capital budgeting practices and decision-making effectiveness", Accounting and Business Research, Vol. 18 No. 72, pp. 341-351.

[29] Pike, R.(1989), "Do sophisticated capital budgeting approaches improve investment decision-making effectiveness?", The Engineering Economist, Vol. 34 No. 2, pp. 149-161.

[30] Pike, R. and Sharp, J. (1989), "Trends in the use of management science techniques in capital budgeting”, Managerial and Decision Economics, Vol. 10 No. 2, pp. 135-140.

[31] Pike,R. (1996),“A longitudinal survey on capital budgeting practices”, Journal of Business Finance and Accounting, Vol. 23 No. 1, pp. 79-92.

[32] Renck, O. (1966), Investeringsbedömning i Några Svenska Företag, P.A. Nordstedt \& Söners förlag, Stockholm.

[33] Ross, S.A., Westerfield, R.W. and Jaffe, J. (2005), Corporate Finance, International Edition, 7th ed, McGraw-Hill, New York.

[34] Ryan, P.A. and Ryan, G.P. (2002), "Capital budgeting practices of fortune 1000: How have things changed?", Journal of Business and Management, Vol. 8 No. 4, pp. 355-364.

[35] Sandahl, G. and Sjögren, S. (2003), "Capital budgeting methods among Sweden's largest groups of companies. The state of the art and a comparison with earlier studies", International Journal of Production Economics, Vol. 84 No 1, pp. 51-69.

[36] Sangster,A. (1993), "Capital investment appraisal techniques: A survey of current usage", Journal of Business Finance and Accounting, Vol. 20 No. 3, pp. 307-332.

[37] Schall, L.D. and Sundem, G.L. (1980), "Capital budgeting methods and risk: A further analysis", Financial Management, Vol. 9 No. 1, pp. 7-11.
[38] Segelod, E. (1995), Resource Allocation in Divisionalized Groups, Aveburty, Aldershot.

[39] Silvola, H. (2006), "Low-intensity R\&D and capital budgeting decisions in IT firms", Advances in Management Accounting, Vol. 15 , pp. 21-49.

[40] Singh, S., Jain, P.K. and Yadav, S.S. (2012), "Capital budgeting decisions: evidence from India", Journal of Advances in Management Research, Vol. 9 No. 1, pp.96-112

[41] Siregar, S.V. and Utama, S. (2008), "Type of earnings management and the effect of ownership structure, firm size, and corporate-governance practices: Evidence from Indonesia", International Journal of Accounting, Vol. 43 No. 1, pp. 1-27.

[42] Smart, S.B., Megginson, W.L. and Gitman, L.J. (2004), Corporate Finance, Thomson South-Western, Mason.

[43] Stanley, M. and Block, S. (1984), "A survey of multinational capital budgeting", FinancialReview, Vol. 19 No. 1, pp. 36-54.

[44] Tell, B. (1978), Investeringsbedömning i Praktiken, Studentlitteratur, Lund.

[45] Truong, G., Partington, G. and Peat, M. (2008), "Cost-of-capital estimation and capital-budgeting practice in Australia”, Australian Journal of Management, Vol. 33 No. 1, pp. 95-122.

[46] Tzovas,C. (2006), "Factors influencing a firm's accounting policy decisions when tax accounting and financial accounting coincide", Managerial Auditing Journal, Vol. 21 No. 4, pp. 372-386.

[47] Verbeeten, F.H.M.(2006), "Do organizations adopt sophisticated capital budgeting practices to deal with uncertainty in the investment decision? A research note", Management Accounting Research, Vol. 17 No. 1, pp. 106-120.

[48] Warfield, T.D., Wild, J.J. and Wild, K.L. (1995), "Managerial ownership, accounting choices, and informativeness of earnings", Journal of Accounting and Economics, Vol. 20 No. 1, pp. 61-91.

[49] Watts, R.L. and Zimmerman, J.L. (1990), "Positive accounting theory: A ten year perspective”, The Accounting Review, Vol. 65 No. 1, pp. 131-156.

[50] Yard, S. (1987), Kalkyllogik och Kalkylkrav, Ph.D. Dissertation, Lund University Press, Lund.

\section{Appendix 1}

The questionnaire (English translation of questions)

Instructions:1) The survey concerns investment- and financing issues that are decided at top management or board level in the parent company/group. This is a top management perspective and the survey questions do not apply to small routine decisions. 2) When questions are asked about investments below, tangible (e.g. properties) as well as intangible (e.g. R\&D) and financial investments (e.g. corporate acquisitions) are referred to. The questions regarding investments apply to all non-routine investments decided at top management or board level in the parent company/group.

\section{Please notice: Fill in one (1) square per line.}

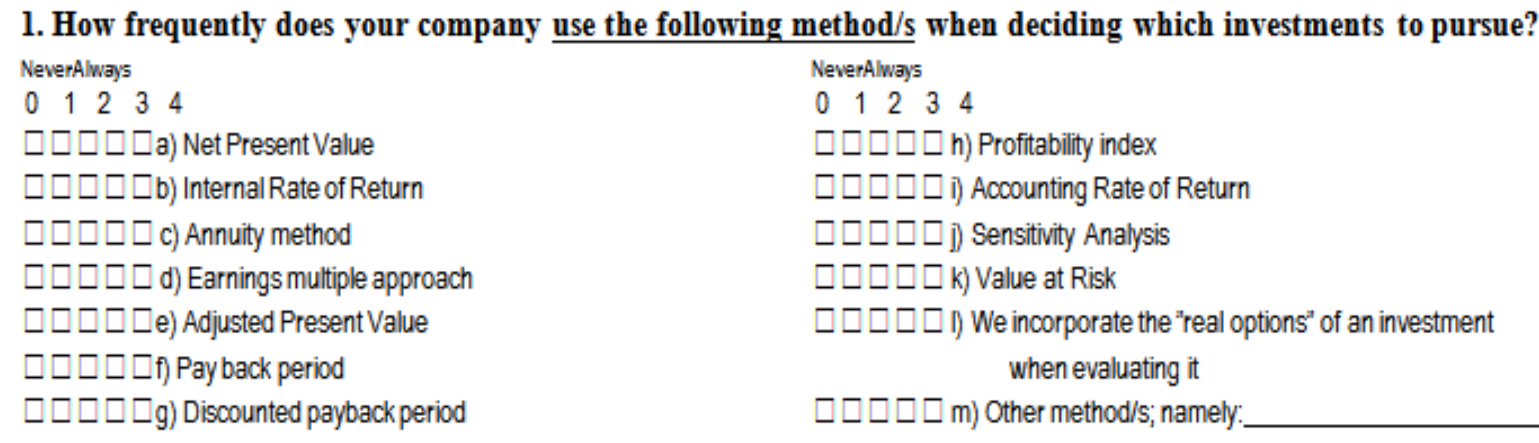


2. How frequently does your company use the following discount rate/s when making investments in foreign count ries? To evaluate projects in foreign countries, we use...

NeverAlways

$\begin{array}{lllll}0 & 1 & 2 & 3 & 4\end{array}$

$\square \square \square \square \square a)$ a discount rate that is normally used for investments in Sweden

$\square \square \square \square \square$ b) the discount rate for the overseas market (country discount rate)

$\square \square \square \square \square c$ ) a divisional discount rate (if the project line of business matches a domestic, i.e. Swedish, division)
NeverAlways

$\begin{array}{lllll}0 & 1 & 2 & 3 & 4\end{array}$

$\square \square \square \square \square$ d) a risk-matched discount rate for this particular project (considering both country risk and divisional risk)

$\square \square \square \square \square$ e) a different discount rate for each component cashflow that has a different risk characteristic

$\square \square \square \square \square$ f) other method/s; namely:

3. Does your company estimate the cost of equity? Yes $\square$ No $\square($ If "No", please skip to question 4). If "Yes"; how do you estimate/determine the cost of equity in your company?

NeverAlways

$\begin{array}{llllll}0 & 1 & 2 & 3 & 4\end{array}$

ロロロロロa) With average historical returns on common stock

$\square \square \square \square \square$ b) Using the Capital Asset Pricing Model (CAPM)

$\square \square \square \square \square c)$ Using the CAPM but including som extra "risk Factors"
NeverAlways

$\begin{array}{llllll}0 & 1 & 2 & 3 & 4\end{array}$

$\square \square \square \square \square$ d) Whatever return our investors tell us they require will determine the cost of equity

$\square \square \square \square \square$ e) By (political) decisions which regulate the required return

$\square \square \square \square \square$ f) The cost of equity is deduced from the following equation: Price $=$ Dividens $/$ (cost of equity - Growth $)$

पवस्व g) Other method/s; namely:

4. When valuing an investment, do you adjust either the discount rate and/or the cashflows, for the following risk factors?

WE ADJUST
discou- cash- both neither
ntrate fows
$\square \square \square \square$ a) Risk of unexpected inflation
$\square \square \square \square$ b) Interest rate risk (change in the general
level of interest rates)
$\square \square \square \square$ c) GDP or business cycle risk
$\square \square \square \square$ d) Term structure risk (change in the long-
term vs. short term interest rate)
$\square \square \square \square$ e) Commodity price risk

\begin{abstract}
WE ADJUST
discou- cash- both neither

ntrate flows

ロロロロ f) Foreign exchange risk

$\square \square \square \square \mathrm{g}$ ) Distress risk (probability of bankruptcy)

ロロロ h) Size (small companies being riskier)

$\square \square \square \square$ i) Market value in relation to book value
\end{abstract}

(=Market value of equity + total debt divided by book value of assets)

$\square \square \square \square$ j) The recent development of the share price

ロロロロ k) Other factor/s; namely:

\section{What factors affect your company's choice between short- and long term debt?}

\begin{tabular}{|c|c|c|c|}
\hline $\begin{array}{l}\text { Not } \\
\text { important }\end{array}$ & $\begin{array}{l}\text { Very } \\
\text { important }\end{array}$ & $\begin{array}{l}\text { Not } \\
\text { important }\end{array}$ & $\begin{array}{l}\text { Very } \\
\text { important }\end{array}$ \\
\hline 012 & 34 & 012 & 34 \\
\hline
\end{tabular}

$\square \square \square \square \square$ a) We use short term debt when short term interest rates are low compared to long term interest rates

ロロロロ b) We match the maturity of our debt with the life of our assets

$\square \square \square \square \square$ c) We use short-term debt when we expect long-term market interest rates to declince

$\square \square \square \square \square$ d) We borrow short-term debt so that returns from new investments can be captured more fully by shareholders, rather than committing to pay long-term profits as interest to debtholders $\square \square \square \square \square$ e) We expect our credit rating to improve, so we borrow short-term until it does

$\square \square \square \square \square$ f) Borrowing short-term reduces the chance that our company will want to take on risky projects

$\square \square \square \square \square g$ ) Vi use long-term debt to minimise the risk of having to refinance in "bad times"

ロロロロ h) Other factor/s; namely:

6. Has your company considered borrowing money (alternatively issuing debt) in foreign countries? Yes $\square$ No $\square$ (If "No", please skip to question 7). If "Yes"; what factors affect such a decision?

\begin{tabular}{lllll} 
Not & \multicolumn{3}{l}{ Very } \\
important & \multicolumn{2}{l}{ important } \\
$\begin{array}{llllll}0 & 1 & 2 & 3 & 4\end{array}$
\end{tabular}

ロロロロロa) Favourable tax treatment relative to Sweden (e.g. different corporate tax rates)

$\square \square \square \square \square$ b) Keeping the "source of funds' close to the "use of funds

$\square \square \square \square \square c)$ Providing a "natural hedge" (e.g. if the foreign currency devalues, we are not obligated to pay the interest in SEK) $\begin{array}{ll}\text { Not } & \text { Very } \\ \text { important } & \text { important }\end{array}$

$\begin{array}{lllll}0 & 1 & 2 & 3 & 4\end{array}$

$\square \square \square \square \square$ d) Foreign regulations require us to borrow/issue debt abroad

$\square \square \square \square \square$ e)Foreign interest rates may be lower than Swedish interest rates

ロロロロロ f) Other factor/s; namely: 
7. Has your company considered issuing convertible debt? Yes $\square$ No $\square$ (If "No", please skip to question 8). If "Yes"; what factors affect such a decision?

Not Very

important important

$\begin{array}{lllll}0 & 1 & 2 & 3 & 4\end{array}$

$\square \square \square \square \square$ a) Convertibles are an inexpensive way to issue "delayed" common stock

ロロロロー b) Protecting bondholders against unfavorable actions by managers or stockholders

ロロロロロc) Convertibles are less expensive than straight debt

ロロロロロ d) Other companies in our industry successfully use convertibles

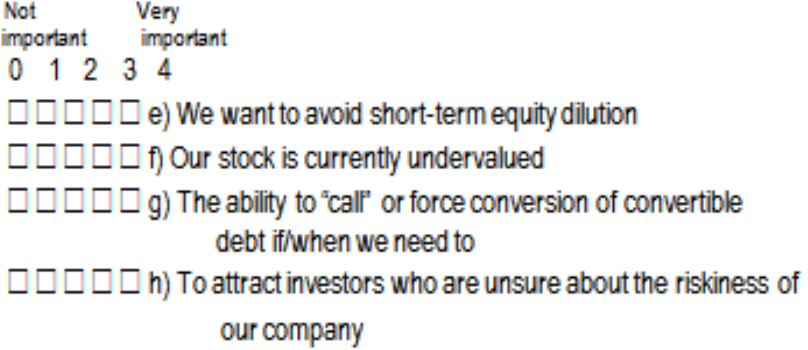

8. Has your company considered issuing shares? Yes $\square$ No $\square($ If "No", please skip to question 9). If "Yes"; what factors affect your company's decision to issue shares?

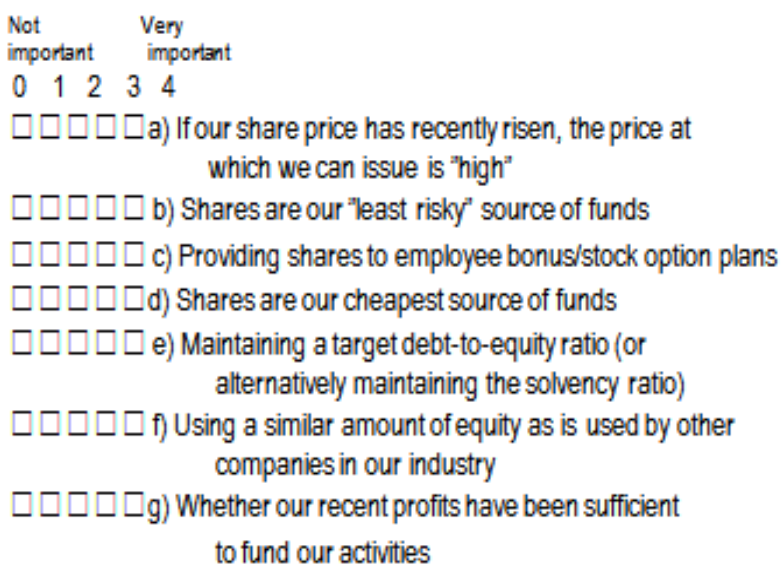

\section{Does your company have a target range for the solvency (or the debt-to-equity) ratio? Please, choose one of the} alternatives.

\section{$\square$ No target range}

$\square$ Yes, a flexible target range (=the aim is that the solvency/debt-to-equity ratio should be within a wide range)

$\square$ Yes, a somewhat tight target range (-the aim is that the solvency/debt-to-equity ratio should be within a relatively narrow range)

$\square$ Yes, a strict target range (=the aim is that the solvency/debt-to-equity should ratio be at, or very close to, a certain percentage figure)

\section{What factors affect how you choose the appropriate amount of debt for you company?}

\section{Not Very}

important important

$\begin{array}{lllll}0 & 1 & 2 & 3 & 4\end{array}$

ロロロロロa) The tax advantage of interest deductability

$\square \square \square \square \square$ b) The potential costs of bankruptcy, near bankruptcy or financial distress

ロロロロロ c) The debt levels of other companies in our industry

ロロロロロ d) Our credit rating (as assigned by rating agencies)

पロロロ e) The transaction costs and fees for ledning and issuing debt

ロロロロ f) The personal tax costs our investors (=the lenders and the bond holders) face when they receive interest income

ロロロロ g) Financial flexibility (we restrict debt so we have enough internal funds available to pursue new projects when they come along)

ロロロロロ h) The volatility of our earnings and cash flows

$\begin{array}{ll}\text { Not } & \text { Very } \\ \text { important } & \text { important }\end{array}$

$\begin{array}{llllll}0 & 1 & 2 & 3 & 4\end{array}$

ロロロロロi) We limit debt so our customers/suppliers are not worried about our company going out of business

ロロロロロj) We try to have enough debt so that we are not an attractive takeover target

ロロロロ k) If we increase debt our competitors know that we are very unlikely to reduce our output

ロロロロロ I) A high debt ratio helps us bargain for concessions from trade unions/our employees

ロロロロロ m) To ensure that upper management works hard and efficiently, we keep a debt level that is sufficiently high (when the debt level is "sufficiently high", a large portion

of our cash flow is committed to interest payments)

ロロロロロ n)We restrict our borrowing so that profits from new/future projects can be captured fully by shareholders and do not have to be paid out as interest to debtholders

ロロロロロ o) Other factor/s; namely 
11. What other factors affect your company's debt policy?

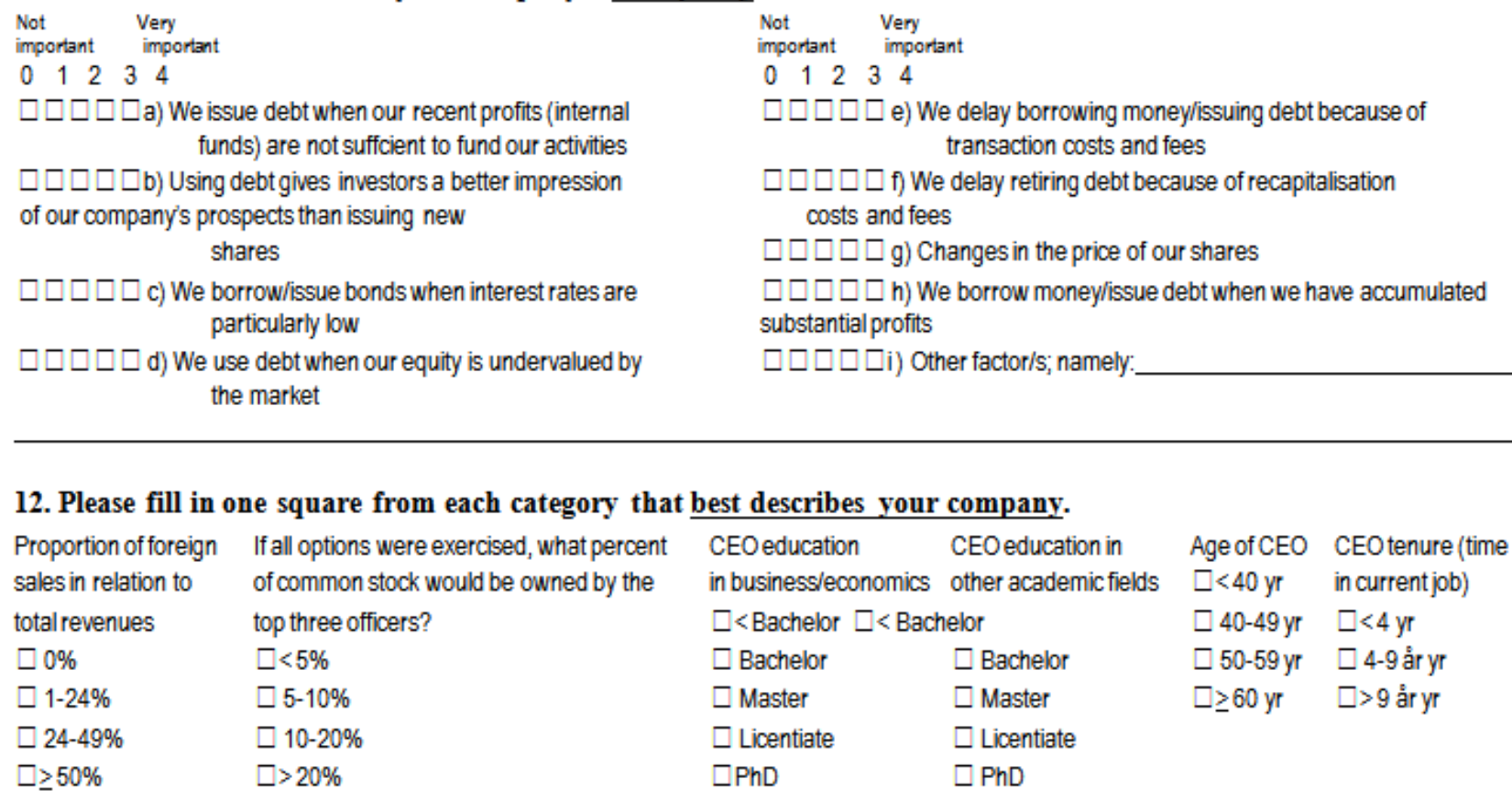

THANK YOU VERY MUCHfor completing this survey! Please return the completed survey in the enclosed stamped envelope to us by JUNE 16 .

\section{Appendix 2}

Table A1. Non-response analysis. Probit regression. Dependent variable equals one if the company respondedto the survey, otherwise zero Independent variable

$\begin{array}{cc}\text { Estimate } & \text { z-value } \\ 6.66 \mathrm{e}-09^{* *} & 2.78 \\ -0.00092 & -0.31 \\ -0.00029 & -0.57 \\ 0.00047 & 0.54 \\ 0.014 & 0.12 \\ -0.20^{*} & -1.70 \\ 0.02 & \\ 493 & \end{array}$

$* * *=$ significant at the $1 \%$ level, $* *=$ significant at the $5 \%$ level, $*=$ significant at the $10 \%$ level.

\section{Appendix 3}

Table A2. Pearson correlation coefficients of independent variables used in the empirical analysis

\begin{tabular}{|c|c|c|c|c|c|c|c|c|c|c|c|c|}
\hline & SIZE & LEVERAGE & GROWTH & TARGET_DEBT & MAN_OWN & CEOEDUC & CEOAGE & CEOTENURE & DMAN & DIVPAY & FSALES & DYEAR \\
\hline SIZE & 1 & & & & & & & & & & & \\
\hline LEVERAGE & 0,058 & 1 & & & & & & & & & & \\
\hline GROWTH & 0,026 & 0,026 & 1 & & & & & & & & & \\
\hline TARGET_DEBT & $-0,038$ & $0,240 * * *$ & $0,197 * * *$ & 1 & & & & & & & & \\
\hline MAN_OWN & $-0,161^{* *}$ & 0,023 & $-0,049$ & $-0,122$ & 1 & & & & & & & \\
\hline CEOEDUC & 0,002 & 0,077 & $-0,037$ & $-0,060$ & 0,040 & 1 & & & & & & \\
\hline CEOAGE & $0,210 * * *$ & $-0,003$ & 0,054 & $-0,016$ & 0,113 & $-0,228 * * *$ & 1 & & & & & \\
\hline CEOTENURE & $-0,006$ & 0,105 & $-0,064$ & $-0,035$ & $0,426 * * *$ & $-0,150 * *$ & $0,277 * * *$ & 1 & & & & \\
\hline DMAN & 0,112 & 0,028 & 0,014 & $-0,099$ & $-0,048$ & $-0,053$ & $-0,074$ & 0,098 & 1 & & & \\
\hline DIVPAY & $0,165 * *$ & 0,046 & 0,321 & 0,089 & $-0,111$ & 0,065 & 0,045 & 0,007 & 0,058 & 1 & & \\
\hline FSALES & 0,166 & $-0,0125$ & $-0,149$ & $-0,129 *$ & 0,001 & $-0,095$ & 0,020 & 0,118 & $0,378 * * *$ & 0,026 & 1 & \\
\hline DYEAR & 0,090 & 0,086 & $-0,073$ & $-0,002$ & $-0,010$ & $0,480 * * *$ & $-0,118$ & $-0,061$ & 0,035 & 0,037 & $-0,111$ & 1 \\
\hline
\end{tabular}

$* * *=$ significant at the $1 \%$ level, **=significant at the $5 \%$ level, $*=$ significant at the $1 \%$ level. 